\title{
Peertechz
}

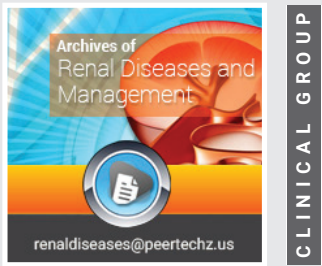

\section{Possible effect of}

\section{dialysis membrane in}

\section{polymethylmethacrylate on}

\section{clinical variables associated with atherosclerosis development in chronic renal failure patients}

\section{Patrizio Imperiali', Chiara Ralli', Diletta Duranti ${ }^{1}$, Carla Clienti ${ }^{2}$, Maria Elena Liberti ${ }^{2}$, Antonio Selvi ${ }^{3}$, Raffaela Sciri ${ }^{3}$, Franco Logias ${ }^{4}$, Pasquale Guastaferro ${ }^{5}$, Filomena Petito ${ }^{5}$, Roberto Rubino ${ }^{6}$, Luigi Albanese ${ }^{6}$, Patrizia Scalia ${ }^{7}$, Mario Bonomini ${ }^{8}$, Lorenzo Di Liberato ${ }^{8}$, Vincenzo Bruzzese $^{9}$, Annamaria Bruzzese ${ }^{9}$, Alessandro Castiglioni ${ }^{10}$ and Ennio Duranti ${ }^{1 *}$}

'Department of Nephrology, Dialysis Hospital of Arezzo, Italy

${ }^{2}$ Dialysis Center, Dial Gest S.r.l, Casoria, Italy

${ }^{3}$ Department of Nephrology and Dialysis, Hospital “Media Valle del Tevere”, Pantalla, Italy ${ }^{4}$ Department of Nephrology and Dialysis, Hospital S. Francesco, Nuoro, Italy ${ }^{5}$ Department of Nephrology and Dialysis, Presidio Ospedaliero "G. Criscuoli", S. Angelo dei Lombardi, Italy

${ }^{6}$ Dialysis Center, Emodialisi Irpina S.r.I, Grottaminarda, Italy

${ }^{7}$ Department of Nephrology and Dialysis, Hospital "Galmarini", Tradate, Italy ${ }^{8}$ Department of Nephrology and Dialysis, Hospital "SS. Annunziata", Chieti, Italy ${ }^{9}$ Department of Nephrology and Dialysis, Civil Hospital "Principessa di Piemonte", Taurianova, Italy ${ }^{10}$ Department of Nephrology and Dialysis, Ospedale di Circolo, Busto Arsizio, Italy

Received: 20 December, 2021

Accepted: 03 January, 2022

Published: 04 January, 2022

*Corresponding author: Ennio Duranti, Department of Nephrology, Dialysis hospital of Arezzo, Via Pietro Nenni 20-22, 52100 Arezzo, Italy, Tel: +39 3803198372; Fax: 00390575910966; E-mail: enniodil@libero.it ORCID: https://orcid.org/0000-0002-7426-7280 Copyright License: (c) 2022 Imperiali P, et al. This is an open-access article distributed under the terms of the Creative Commons Attribution License, which permits unrestricted use, distribution, and reproduction in any medium, provided the original author and source are credited.

https://www.peertechzpublications.com

Check for updates

\section{Abstract \\ Background: Chronic hemodialysis patients have higher cardiovascular morbidity compared to the general population. A number of studies have suggested that patients undergoing hemodialysis with polymethylmethacrylate (PMMA) membranes have a better outcome compared to other membranes.}

Methods: We performed a retrospective, multicenter study to evaluate the impact of PMMA membranes compared to other types of membranes on clinical parameters considered important risk factors for the development of cardiovascular disease in chronic kidney disease patients.

Results: The study included 104 patients (52 patients on PMMA and 52 patients on other membranes) from ten dialysis centers, monitored for 24 months. HDL cholesterol (mg/dL) increased significantly in the PMMA group ( $41.4 \pm 10.8$ to $44.1 \pm 13.5, p=0.0467)$, but not in the control group (41.8 \pm 13.8 to $39.4 \pm 9.6$, $p=0.8628)$. At 24 months total cholesterol and triglycerides $(\mathrm{mg} / \mathrm{dl})$ were significantly lower in the PMMA group than in the control group $(142.4 \pm 43.8 \mathrm{vs}$. $166.1 \pm 43.4, \mathrm{p}=0.0321$ and $106(76.5-176)$ vs. $170(118-254), p=0.014)$, respectively. Serum creatinine (mg/dL) increased significantly from baseline to $24 \mathrm{months}$ in the PMMA group (9.20 \pm 
2.5 to $9.47 \pm 2.3, p=0.0291)$, but not in the patients treated with other membranes $(8.39 \pm 2.6$ to $8.37 \pm 2.3, p=0.2743)$. In addition creatinine was significantly higher in the PMMA group compared to the other group $(9.47 \pm 2.3$ vs. $8.37 \pm 2.3, p=0.0493)$

WBCs $\left(10^{9} / \mathrm{L}\right)$ increased significantly in the control group $(6151 \pm 1846$ to $6672 \pm 1872, p=0.0457)$ but not in the PMMA group $(6326 \pm 2113$ to $6152 \pm 1832, p=0.8981)$. At 24 months platelets $\left(10^{9} / \mathrm{L}\right)$ and CRP ( $\left.\mathrm{ng} / \mathrm{dL}\right)$ were significantly lower in the PMMA group compared to the control group (185 (144-222) vs. 210 (173-259), $\mathrm{p}=0.0498$ and $0.70(0.30-1.59)$ vs. $3.76(0.46-10.2), p=0.023$, respectively). Iron and transferrin $(\mu \mathrm{g} / \mathrm{dL})$ decreased signifi cantly in the patients treated with other membrane $(62.5 \pm 30.4$ to $52.6 \pm 19.0, p=0.0113$ and $178(157-218)$ to $170(124-203), p=0.0019$, respectively), but not in the PMMA group.

Conclusion: This retrospective study of data from 104 patients shows a favorable effect of PMMA on clinical variables considered relevant for the development of atherosclerosis in hemodialysis patients.

\section{Introduction}

In chronic hemodialysis patients, morbidity and mortality due to cardiovascular disease are considerably higher compared to the general population. Several studies have shown that traditional risk factors for cardiovascular diseases, such as diabetes, smoking, higher systolic pressure, elevated total cholesterol and decreased High-Density Lipoprotein (HDL) are important factors in the development of atherosclerosis in Chronic Kidney Disease (CKD) patients [1]. CKD patients with low HDL levels have a poor prognosis [2]. Inflammation also appears to play an important role in the pathology of atherosclerosis in these patients. C-Reactive Protein (CRP) is a well-known marker for inflammation and may play an active role in cardiovascular disease [3]. White Blood Cell (WBC) count is a traditional indicator of inflammation and infection responses and previous studies revealed the significant association of WBC count and adverse cardiovascular outcome in dialysis patients [4,5]. A 2016 study seems to confirm that platelet count is associated with an increase in vascular mortality, future cardiovascular disease, and future cancer in a cohort study population not on dialysis [6-8]. Other inflammatory markers, like the cytokines TNF- $\alpha, \mathrm{IL}-6$ and IL10 may play a role [9]. Hyperinsulinemia and insulin resistance are common in kidney disease and have been shown to correlate with cardiovascular disease mortality in patients with endstage renal disease [10]. Elevated level of Homocysteine (tHcy) has been associated with increased morbidity and mortality in patients with kidney failure [11]. Abnormal mineral metabolism can promote arterial calcification and arterial stiffness and hyperphosphatemia and elevated calcium phosphate product may be involved in cardiovascular disease in kidney failure [12]. Anemia correlates with cardiovascular disease mortality and morbidity [13].

A number of studies have suggested that patients undergoing hemodialysis with Polymethylmethacrylate (PMMA) membranes have a better outcome in terms of morbidity and mortality compared to other membranes [14-17]. The present study aimed to evaluate the behavior of the numerous parameters involved in the progression of atherosclerotic processes or in predicting the progression of cardiovascular events, during a period of 24 months of dialysis treatment with PMMA membranes, compared with a group of patients treated with other membrane types.

\section{Materials and methods}

\section{Study design}

The study was a retrospective multicenter study to investigate the possible effect of PMMA on clinical variables considered relevant for the development of atherosclerosis in chronic renal failure patients undergoing hemodialysis with dialyzers in Polymethylmethacrylate (PMMA) compared to other types of membranes. The primary objective of this study was to study the effect of the PMMA dialyzer on various biochemical and clinical parameters that have been identified as important risk factors for the development of cardiovascular disease in chronic kidney disease patients.

\section{Patient characteristics and enrollment criteria}

Among all patients from the participating centers, patients were enrolled in the study if they had undergone bicarbonate hemodialysis for at least two years, were aged 40-75 years and had not had any previous incidence of cancer, cardiovascular disease (especially ischemic heart disease also excluding episodes of anginal type) or serious infections (i.e. requiring hospitalization). Patients who were treated with PMMA and patients who were treated with other types of membranes were equally distributed according to age, sex, dialysis vintage weight loss/6 months and $\mathrm{Kt} / \mathrm{V}$ in order to have a balanced distribution in the two study groups.

\section{Clinical and laboratory parameters}

We collected data on biochemical and clinical parameters that have been identified as important risk factors for the development of cardiovascular disease in chronic kidney disease patients. Biochemical parameters were collected every 6 months over a period of 2 years and included variables related to nutritional condition end dialysis efficiency (total protein, albumin, Kt/v, creatinine, urea, uric acid), lipidic profile (total cholesterol, HDL cholesterol, LDL cholesterol, triglycerides), inflammatory factors (white blood cells, platelets, CRP), iron status (ferritin, hemoglobin, iron, transferrin) and mineral metabolism (calcium, phosphate, product CaxP).

\section{Statistical analysis}

Normality tests were performed using the KolmogorovSmirnov test. Quantitative normally distributed variables are presented as mean \pm Standard Deviation (SD) and non-normally distributed variables as median and the $25^{\text {th }}-75^{\text {th }}$ quartiles range. Univariate comparison was performed to compare variables between two groups. In all comparisons $\mathrm{p}<0.05$ was considered statistically significant. Student's t-test, Wilcoxon test and Mann-Whitney test were used to compare means in case of normal paired or unpaired samples, non-normal paired samples and non-normal unpaired samples, respectively.

Citation: Imperiali P, Ralli C, Duranti D, Clienti C, Duranti E, et al. (2022) Possible effect of dialysis membrane in polymethylmethacrylate on clinical variables associated with atherosclerosis development in chronic renal failure patients. Arch Renal Dis Manag 7(1): 001-005. 


\section{Results}

A total of 104 patients were enrolled in the study, 52 patients underwent hemodialysis with PMMA membranes and 52 patients were treated with other types of membranes. Ten Italian dialysis centers contributed to this study. Baseline characteristics are shown in Table 1. No significant difference was present between the two patient groups. There was no change in the pharmaceutical therapies given to the patients during the observation period.

Table 2 summarizes biochemical parameters at baseline (To) and after 24 months (T24) for patients treated with PMMA and patients treated with other membrane types. There were no significant differences between the two groups at baseline. Serum total proteins and albumin did not change after 24 months and within the two groups. Serum creatinine $(\mathrm{mg} /$ $\mathrm{dL}$ ) increased significantly from baseline to T24 in the PMMA group $(9.20 \pm 2.5$ to $9.47 \pm 2.3, \mathrm{p}=0.0291)$, but not in the group patients treated with other membranes $(8.39 \pm 2.6$ to $8.37 \pm 2.3$, $\mathrm{p}=0.2743$ ). At 24 months creatinine was significantly higher in the PMMA group compared to the other group $(9.47 \pm 2.3$

Table 1: Baseline characteristics.

\begin{tabular}{|c|c|c|c|}
\hline Variables & $\begin{array}{c}\text { Polymethylmethacrylate } \\
\text { (PMMA) }\end{array}$ & $\begin{array}{c}\text { Other membrane } \\
\text { types }\end{array}$ & Significance \\
\hline Sample size & 52 & 52 & n.s. \\
Gender (\% male) & 70.8 & 51.2 & n.s. \\
Body weight (kg) & $70.3 \pm 15.6$ & $71.7 \pm 19.4$ & n.s. \\
BMI & $25.3 \pm 5.1$ & $26.2 \pm 5.7$ & n.s. \\
Smoking (\%) & 8.6 & 9.1 & n.s. \\
Diabetes (\%) & 32.5 & 31.1 & n.s. \\
Age (Years) & $74.0(63.8-79.0)$ & $70.5(60.8-78.0)$ & n.s. \\
Dialysis vintage & $5.0(3.2-7.0)$ & $4.4(2.6-7.0)$ & n.s. \\
(years) & & & \\
\hline
\end{tabular}

Normally distributed data are expressed as mean \pm SD and non-normally distributed data as median (interquartile range)

n.s., non-significant vs. $8.37 \pm 2.3, \mathrm{p}=0.0493)$. All other parameters did not change significantly between the two groups and during 24 months.

HDL cholesterol $(\mathrm{mg} / \mathrm{dL})$ increased significantly in the PMMA group ( $41.4 \pm 10.8$ to $44.1 \pm 13.5, \mathrm{p}=0.0467)$, but not in the other group $(41.8 \pm 13.8$ to $39.4 \pm 9.6, p=0.8628)$. At 24 months total cholesterol and triglycerides $(\mathrm{mg} / \mathrm{dL})$ were significantly lower in the PMMA group than in the other group $(142.4 \pm 43.8$ vs. $166.1 \pm 43.4, \mathrm{p}=0.0321$ and $106(76.5-176)$ vs. $170(118-254), \mathrm{p}=0.014$, respectively . LDL $(\mathrm{mg} / \mathrm{dL}) \mathrm{did}$ not change significantly between the two groups and during 24 months.

Among inflammatory markers WBCs $\left(10^{9} / \mathrm{L}\right)$ increased significantly in the group treated with other membranes (6151 \pm 1846 to $6672 \pm 1872, \mathrm{p}=0.0457$ ) but not in the PMMA group $(6326 \pm 2113$ to $6152 \pm 1832, \mathrm{p}=0.8981)$. At 24 months platelets $\left(10^{9} / \mathrm{L}\right)$ and CRP $(\mathrm{ng} / \mathrm{dL})$ were significantly lower in the PMMA group compared to the other group (185 (144-222) vs. 210 (173259), $\mathrm{p}=0.0498$ and $0.70(0.30-1.59)$ vs. $3.76(0.46-10.2), \mathrm{p}=$ 0.023 , respectively ).

Iron and transferrin $(\mu \mathrm{g} / \mathrm{dL})$ decreased significantly in the patients treated with other membrane $(62.5 \pm 30.4$ to $52.6 \pm$ $19.0, p=0.0113$ and 178 (157-218) to 170 (124-203), $\mathrm{p}=0.0019$, respectively), but not in the PMMA group. No difference within and between the two groups as regards $\mathrm{Hb}$ and Ferritin. There was no significant difference as regards $\mathrm{Ca}, \mathrm{P}$ and calciumphosphate product between and within any of the two groups. B2-microglobulin did not change in any period and within any group.

\section{Discussion}

End stage renal disease (ESRD) has become a prototype for chronic inflammation. There is consistent evidence that CRP and pro-inflammatory cytokines, such as IL-1, IL-6 and TNF- $\alpha$ are risk factors for atherosclerotic complications and

Table 2: Biochemical parameters.

\begin{tabular}{|c|c|c|c|c|}
\hline \multirow{2}{*}{ Variables } & \multicolumn{2}{|c|}{ PMMA membrane $(n=52)$} & \multicolumn{2}{|c|}{ Other membrane type $(n=52)$} \\
\hline & TO & $\mathrm{T} 24$ & TO & T24 \\
\hline $\mathrm{Kt} / \mathrm{V}$ & $>1.2$ & $>1.2$ & $>1.2$ & $>1.2$ \\
\hline Total protein $(\mathrm{g} / \mathrm{dL})$ & $6.26 \pm 0.5$ & $6.40 \pm 0.5$ & $6.37 \pm 0.5$ & $6.36 \pm 0.4$ \\
\hline Creatinine (mg/dL) & $9.20 \pm 2.5$ & $9.47 \pm 2.3^{\mathrm{a}}$ & $8.39 \pm 2.6$ & $8.37 \pm 2.3^{b}$ \\
\hline Urea (mg/dL) & $122.4 \pm 44.7$ & 114.046 .8 & $128.3 \pm 49.5$ & 123.649 .8 \\
\hline Total cholesterol (mg/dL) & $153.5 \pm 41.7$ & $142.4 \pm 43.8^{b}$ & $167.0 \pm 43.7$ & $166.1 \pm 43.4^{b}$ \\
\hline HDL cholesterol (mg/dL) & $41.4 \pm 10.8$ & $44.1 \pm 13.5^{\mathrm{a}}$ & $41.8 \pm 13.8$ & $39.4 \pm 9.6$ \\
\hline LDL cholesterol (mg/dL) & $94.8 \pm 46.2$ & $92.0 \pm 31.2$ & $86.1 \pm 22.8$ & $77.8 \pm 27.5$ \\
\hline White blood cells $\left(10^{9} / \mathrm{L}\right)$ & $6326 \pm 2113$ & $6152 \pm 1832$ & $6151 \pm 1846$ & $6672 \pm 1872^{a}$ \\
\hline Hemoglobin (g/dL) & $11.3 \pm 1.17$ & $11.3 \pm 1.78$ & $11.5 \pm 1.19$ & $11.2 \pm 1.38$ \\
\hline Iron (g/dL) & $55.0 \pm 21.9$ & $57.6 \pm 35.0$ & $62.5 \pm 30.4$ & $52.6 \pm 19.0^{\mathrm{a}}$ \\
\hline $\operatorname{CaxP}\left(\mathrm{mg}^{2} / \mathrm{dL}^{2}\right)$ & $43.7 \pm 12.9$ & $46.1 \pm 18.2$ & $45.5 \pm 13.1$ & $50.2 \pm 14.8$ \\
\hline Albumin $(\mathrm{g} / \mathrm{dL})$ & $3.70(3.30-3.90)$ & $3.80(3.30-3.99)$ & $3.79(3.60-3.97)$ & $3.80(3.43-4.05)$ \\
\hline Uric acid (mg/dL) & $5.70(5.00-6.45)$ & $6.3(5.60-6.60)$ & $5.50(4.33-6.90)$ & $6.10(4.88-6.70)$ \\
\hline Triglycerides (mg/dL) & $122(91.3-169)$ & $106(76.5-176)^{b}$ & $157(118-228)$ & $170(118-254)^{\mathrm{b}}$ \\
\hline Platelets $\left(10^{9} / \mathrm{L}\right)$ & $184(141-228)$ & $185(144-222)^{\mathrm{b}}$ & $190(154-250)$ & $210(173-259)^{b}$ \\
\hline CRP (ng/dL) & $1.60(0.45-3.03)$ & $0.70(0.30-1.59)^{\mathrm{b}}$ & $1.95(0.80-3.52)$ & $3.76(0.46-10.2)^{b}$ \\
\hline Ferritin $(\mu \mathrm{g} / \mathrm{dL})$ & $243(76.2-566)$ & $143(47.3-416)$ & $246(52.8-435)$ & $193(98.4-390)$ \\
\hline Transferrin $(\mu \mathrm{g} / \mathrm{dL})$ & $178(147-219)$ & $189(171-205)$ & $178(157-218)$ & $170(124-203)^{a}$ \\
\hline B2-microglobulin (mg/dL) & $32.7(30.6-36.7)$ & $37.5(29.7-43.7)$ & $32.3(26.3-42.2)$ & $34.5(32.8-38.0)$ \\
\hline
\end{tabular}

Normally distributed data are expressed as mean \pm SD and non-normally distributed data as median (interquartile range)

a $p<0.05$ for T0 vs. T24 within the same group, ${ }^{b} p<0.05$ between groups

Citation: Imperiali P, Ralli C, Duranti D, Clienti C, Duranti E, et al. (2022) Possible effect of dialysis membrane in polymethylmethacrylate on clinical variables associated with atherosclerosis development in chronic renal failure patients. Arch Renal Dis Manag 7(1): 001-005. 
predict death and adverse cardiovascular outcomes [18-20]. Levels of CRP increase as the renal function deteriorates and are particularly high in HD patients. Our study highlights the significant positive impact of the PMMA membrane, known for its high adsorption capacity and biocompatibility, in reducing CRP levels after a period of two years, compared to other membranes. It has been suggested that the rapidly developing atherosclerosis in ESRD patients could be caused by a synergism of different mechanisms such as malnutrition, inflammation, and oxidative stress [18-20]. In our study, BMI did not show any state of malnutrition among the patients of the two groups in a period of the 24 months considered. With regard to PMMA, compared to other membranes, it seems very likely that the significant increase in creatinine at 24 months depends on an increase in the weight of the patients. In this case, we advance the possibility that serum creatinine level depends not only on muscle mass but also on muscle quality, as reported by MBPajec in a work of 2018 [21]. In their work, the authors concluded that each $\mathrm{kg}$ of lean body mass was associated with $7.7 \mathrm{~mol} / \mathrm{l}$ or $0,09 \mathrm{mg} / \mathrm{dL}$ increase in serum creatinine concentration. Thus confirming a better condition of anabolism linked to the use of PMMA, which also contributes to better control of the progression of atherosclerosis.

Some therapeutic approaches have been suggested, such as antioxidant therapy and ACE inhibitors [22] together with statins that might be able to reduce CRP levels [23,24]. We emphasize that drug therapies remained unchanged during the two years of observation in the two groups of patients. Schwarz, et al. [6] have shown that coronary atherosclerotic plaques in ESRD patients are characterized by increased medial thickness, infiltration by and activation of macrophages and marked calcification. Serum ferritin may be increased due to noniron-related factors including elements of the malnutritioninflammation complex syndrome. So the probability of having moderately high serum ferritin $\geq 500 \mathrm{ng} / \mathrm{ml}$ can be explained by both iron stores and inflammation. The seemingly paradoxical combination of serum ferritin $\geq 500 \mathrm{ng} / \mathrm{ml}$ and transferrin saturation $<25 \%$ in HD patients is associated with an increased level of inflammatory markers [25]. Hence, in dealing with HD patients with ferritin levels $>500 \mathrm{ng} / \mathrm{ml}$, the possibility of high levels of circulating inflammatory cytokines should be considered as an alternative explanation to iron overload [25]. The diagnostic validity and reliability of serum ferritin in diagnosing anemia and iron treatment adequacy need to be revisited in additional studies.

In our study, patients treated with PMMA membranes showed better control of ferritin and iron concentration linked to the significant reduction of inflammation markers. Concerning WBC count, even if decreased during PMMA treatment, the data is difficult to consider positive on inflammation and then atherosclerosis, because different studies regarding the WBC count as a predictor of clinical outcome are controversial $[4,5,8]$.

Other mechanisms and factors of cardiovascular risk are platelets and their effects on blood viscosity and prothrombotic state that may predispose dialysis patients to cardiovascular events $[6,8]$. For example, the various mechanisms of CD40 receptor and $\mathrm{CD} 40 \mathrm{~L}$ on platelets activation are of particular interest [7]. Binding of CD40L to its $\mathrm{CD} 40$ receptor on endothelial cell and platelet membranes seems to induce an enhanced release of potent proinflammatory and atherosclerosispromoting cytokines and chemokines [7]. The use of PMMA reduced the number of platelets over time, probably due to its reductive effects on the $\mathrm{CD} 40$ fractions. We could not dose CD40 fractions during the present study, however, we emphasize that in our previous studies and other authors, PMMA membrane demonstrated its powerful absorptive capacity with respect to soluble $\mathrm{CD} 40$ and $\mathrm{CD} 40 \mathrm{O}$ inducing an improvement in the immune response, especially during Hepatitis B vaccination [26-31].

The role of hypercholesterolemia as a risk factor for the development of cardiovascular disease in moderate and severe chronic kidney disease is actively debated, mainly because of the inconsistent and often paradoxical relationships reported in observational studies $[32,33]$. CKD patients with low HDL levels have a poor prognosis [2]. In the present study HDL cholesterol increased significantly in the PMMA group, but not in the control group. HD significantly affects lipoprotein metabolism and dyslipidemia through membrane used (high flux vs. low flux), type of dialysate (bicarbonate vs. acetate), anticoagulant (heparin) and the phosphate-binder (sevelamer hydrochloride) [33,34]. We reiterate that dialysis modalities and drug therapies remained unchanged during the two years of observation and BMI remained unmodified.

An effect of confounding factors such as dialysis characteristics, medication, diet or heparin dosage were excluded because these factors were not different in the treatment group and the control group and did not change throughout the study. In conclusion these results establish that hemodialysis with PMMA membranes, with respect to other membranes, has a favorable effect on some of the main metabolic and nutritional parameters and some phlogistic and immunological mechanisms underlying the atherosclerotic processes, therefore its use should find an indication in HD patients at greater cardiovascular risk.

\section{Conclusion}

This retrospective study of data from 104 patients monitored over a period of 24 months from ten Italian dialysis centers, shows a favorable effect of PMMA on clinical variables considered relevant for the development of atherosclerosis in hemodialysis patients. The observed positive effect may be explained by the superior biocompatibility of PMMA compared to other membranes, as well as its adsorptive capacities. Due to the retrospective nature of this study, it was not possible to collect data on specific variables, such as cytokines and components of the CD40 system. It would be interesting to address these issues in a future prospective study.

\section{References}

1. Muntner P, He J, Astor BC, Folsom AR, Coresh J (2005) Traditional and nontraditional risk factors predict coronary heart disease in chronic kidney disease: results from the atherosclerosis risk in communities study. J Am Soc Nephrol 16: 529-538. Link: https://bit.ly/3EOseoV

Citation: Imperiali P, Ralli C, Duranti D, Clienti C, Duranti E, et al. (2022) Possible effect of dialysis membrane in polymethylmethacrylate on clinical variables associated with atherosclerosis development in chronic renal failure patients. Arch Renal Dis Manag 7(1): 001-005. 
2. Baragetti A, Norata GD, Sarcina C, Rastelli F, Grigore L, et al. (2013) High density lipoprotein cholesterol levels are an independent predictor of the progression of chronic kidney disease. J Intern Med 274: 252-262. Link: https://bit.ly/3FPelm5

3. Menon V, Greene T, Wang X, Pereira AA, Marcovina SM, et al. (2005) C-reactive protein and albumin as predictors of all-cause and cardiovascular mortality in chronic kidney disease. Kidney Int 68: 766-772. Link: https://bit.ly/31kNKUt

4. Johnson DW, Wiggins $\mathrm{KJ}$, Armstrong KA, Campbell SB, Isbel NM, et al (2005) Elevated white cell count at commencement of peritoneal dialysis predicts overall and cardiac mortality. Kidney Int 67: 738-743. Link: https://bit.ly/3sSEx0T

5. Hsu CW, Lin JL, Lin-Tan DT, Yen TH, Chen KH (2010) White blood cell count predicts all-cause, cardiovascular disease-cause and infection-cause one-yea mortality of maintenance hemodialysis patients. Ther Apher Dial 14: 552-559. Link: https://bit.ly/3JMvLb4

6. Schwarz U, Buzello M, Ritz E, Stein G, Raabe G, et al. (2000) Morphology of coronary atherosclerotic lesions in patients with end-stage renal failure. Nephrol Dial Transplant 15: 218-223. Link: https://bit.ly/3sSK73C

7. Aloui C, Prigent A, Sut C, Tariket S, Hamzeh-Cognasse H, et al. (2014) The signaling role of CD40 ligand in platelet biology and in platelet component transfusion. Int J Mol Sci 15: 22342-22364. Link: https://bit.ly/3G1s9zm

8. Stach K, Karb S, Akin I, Borggrefe M, Krämer B, et al. (2017) Elevation of Platelet and Monocyte Activity Markers of Atherosclerosis in Haemodialysis Patients Compared to Peritoneal Dialysis Patients. Mediators Inflamm 2017: 8506072-72. Link: https://bit.ly/3pNusk9

9. Stenvinkel P, Ketteler M, Johnson RJ, Lindholm B, Pecoits-Filho R, et al. (2005) IL-10, IL-6, and TNF-alpha: central factors in the altered cytokine network of uremia--the good, the bad, and the ugly. Kidney Int 67: 1216-1233. Link: https://bit.ly/3eMbxQs

10. Shinohara K, Shoji T, Emoto M, Tahara H, Koyama $H$, et al. (2002) Insulin resistance as an independent predictor of cardiovascular mortality in patients with end-stage renal disease. J Am Soc Nephrol 13: 1894-1900. Link: https://bit.ly/31jbqlS

11. Mallamaci F, Zoccali C, Tripepi G, Fermo I, Benedetto FA, et al. (2002) Hyperhomocysteinemia predicts cardiovascular outcomes in hemodialysis patients. Kidney Int 61: 609-614. Link: https://bit.ly/31iOiKv

12. Block GA, Klassen PS, Lazarus JM, Ofsthun N, Lowrie EG, et al. (2004) Mineral metabolism, mortality, and morbidity in maintenance hemodialysis. J Am Soc Nephrol 15: 2208-2218. Link: https://bit.ly/3FUBCIT

13. Foley RN, Parfrey PS, Harnett JD, Kent GM, Murray DC, et al. (1996) The impact of anemia on cardiomyopathy, morbidity, and and mortality in end-stage renal disease. Am J Kidney Dis 28: 53-61. Link: https://bit.ly/3FTSteU

14. Hakim RM, Wingard RL, Parker RA (1994) Effect of the dialysis membrane in the treatment of patients with acute renal failure. N Engl J Med 331: 13381342. Link: https://bit.ly/3FOXZzO

15. Hakim RM, Held PJ, Stannard DC, Wolfe RA, Port FK, et al. (1996) Effect of the dialysis membrane on mortality of chronic hemodialysis patients. Kidney In 50: 566-570. Link: https://bit.ly/32X7q0Z

16. Jorres A, Gahl GM, Dobis C, Polenakovic MH, Cakalaroski K, et al. (1999) Haemodialysis-membrane biocompatibility and mortality of patients with dialysis-dependent acute renal failure: a prospective randomised multicentre trial. Lancet 354: 1337-1341. Link: https://bit.ly/3JDR66v

17. Abe M, Hamano T, Wada A, Nakai S, Masakane I (2017) Effect of dialyze membrane materials on survival in chronic hemodialysis patients: Results from the annual survey of the Japanese Nationwide Dialysis Registry. PloS One 12: e0184424. Link: https://bit.ly/34hRJSY
18. Memoli B (1999) Cytokine production in haemodialysis. Blood Purif 17: 149 158. Link: https://bit.ly/3FPYaum

19. Kalantar-Zadeh K, Kopple JD (2001) Relative contributions of nutrition and inflammation to clinical outcome in dialysis patients. Am J Kidney Dis 38 1343-1350. Link: https://bit.ly/34atiXn

20. Korevaar JC, van Manen JG, Dekker FW, de Waart DR, Boeschoten EW, et al. (2004) Effect of an increase in C-reactive protein level during a hemodialysis session on mortality. J Am Soc Nephrol 15: 2916-2922. Link: https://bit.ly/3HuqKBP

21. Vodičar J, Pajek J , Hadžić V, Paje MB (2018) Relation of Lean Body Mass and Muscle Performance to Serum Creatinine Concentration in Hemodialysis Patients. Biomed Res Int 2018: 4816536. Link: https://bit.ly/3pJTDnz

22. Stenvinkel P, Heimbürger O, Paultre F, Diczfalusy U, Wang T, et al. (1999) Strong association between malnutrition, inflammation, and atherosclerosis in chronic renal failure. Kidney Int 55: 1899-1911. Link: https://bit.ly/32Y0Vva

23. Gabay C, Kushner I (1999) Acute-phase proteins and other systemic responses to inflammation. N Engl J Med 340: 448-454. Link: https://bit.ly/32NV37M

24. Kalantar-Zadeh K, Rodriguez RA, Humphreys MH (2004) Association between serum ferritin and measures of inflammation, nutrition and iron in haemodialysis patients. Nephrol Dial Transplant 19: 141-149. Link: https://bit.ly/3EQPJO5

25. Coyne D (2006) Iron indices: what do they really mean? Kidney Int Suppl S4-S8 Link: https://bit.ly/3qGORX9

26. Mach F, Schönbeck U, Sukhova GK, Bourcier T, Bonnefoy JY, et al. (1997) Functional CD40 ligand is expressed on human vascular endothelial cells, smooth muscle cells, and macrophages: implications for CD40-CD40 ligand signaling in atherosclerosis. Proc Natl Acad Sci U S A 94: 1931-1936. Link: https://bit.ly/3zjYHSM

27. Contin-Bordes C, Lacraz A, Precigout V (2010) Potential role of the soluble form of CD40 in deficient immunological function of dialysis patients: new findings of its amelioration using polymethylmethacrylate (PMMA) membrane. NDT Plus 3: i20-i27. Link: https://bit.ly/3sT2VQk

28. Duranti E, Duranti D (2011) Polymethylmethacrylate strengthens antibody response in hemodialysis patients not responding to hepatitis $B$ vaccine: preliminary data. Minerva Med 102: 469-474. Link: https://bit.ly/3zlAOdz

29. Cantaluppi V, Medica D, Migliori M, Marengo M, Diena D, et al. (2016) Biological effects of polymethylmetacrylate (PMMA) membrane on serum levels of soluble CD40 ligand, a middle molecule involved in atherogenic inflammation and cardiovascular mortality of hemodialysis patients. ERA-EDTA. Vienna, Austra SP609.

30. Duranti E, Duranti D (2016) Adsorptive hemodialysis by polymethylmetacrylate (PMMA): an update on hepatitis $\mathrm{B}$ vaccination immune response. J Chronic Dis Manag 1: 1005. Link: https://bit.ly/3JBHp8j

31. Ralli C, Imperiali P, Gabbrilelli C, Conti P, Lombardi M, et al. (2016) Hemodialysis with polymethylmetacrylate restores the response to hepatitis $B$ vaccination in chronic dialysis patients: Hypothesized mechanism of action. Arch Renal Dis Manag 001-04. Link: https://bit.ly/3EPS103

32. Blankestijn PJ, Vos PF, Rabelink TJ, van Rijn HJ, Jansen H, et al. (1995) Highflux dialysis membranes improve lipid profile in chronic hemodialysis patients. J Am Soc Nephrol 5: 1703-1708. Link: https://bit.ly/3zmrgze

33. Liu Y, Coresh J, Eustace JA, Longenecker JC, Jaar B, et al. (2004) Association between cholesterol level and mortality in dialysis patients: role of inflammation and malnutrition. JAMA 291: 451-459. Link: https://bit.ly/3zmrgze

34. Contreras G, Hu B, Astor BC, Greene T, Erlinger T, et al. (2010) Malnutritioninflammation modifies the relationship of cholesterol with cardiovascular disease. J Am Soc Nephrol 21: 2131-2142. Link: https://bit.ly/3FSzmSp

Citation: Imperiali P, Ralli C, Duranti D, Clienti C, Duranti E, et al. (2022) Possible effect of dialysis membrane in polymethylmethacrylate on clinical variables associated with atherosclerosis development in chronic renal failure patients. Arch Renal Dis Manag 7(1): 001-005. 